\title{
Carbon stocks of an Oxisol after thirty-eight years under different tillage systems
}

\author{
Sulamirtes S. de A. Magalhaes ${ }^{1}$, Fabricio T. $\operatorname{Ramos}^{2}$ \& Oscarlina L. dos S. Weber ${ }^{2}$ \\ ${ }^{1}$ Universidade Federal de Mato Grosso/Instituto de Biociências. Cuiabá, MT. E-mail: sulamorim@yahoo.com.br \\ ${ }^{2}$ Universidade Federal de Mato Grosso/Faculdade de Agronomia, Medicina Veterinária e Zootecnia. Cuiabá, MT. E-mail; fabriciotomazramos@gmail.com \\ (Corresponding author); oscarlinaweber@gmail.com
}

\section{Key words:}

soil conservation

crop rotation

soil organic matter

\begin{abstract}
A B S T R A C T
Soil carbon (C) stock determination can subsidize discussions on the continuity of an agricultural management. This study aimed to evaluate the stocks of total organic $\mathrm{C}$ $\left(\mathrm{S}_{\mathrm{TOC}}\right)$ and labile $\mathrm{C}\left(\mathrm{S}_{\mathrm{LC}}\right)$, and the indices of $\mathrm{C}$ lability (CLI), $\mathrm{C}$ compartment (CCI) and $\mathrm{C}$ management $(\mathrm{CMI})$, and correlate them with chemical and physical attributes of a Red Yellow Latosol (Oxisol) managed for 38 years with different tillage systems in a Cerrado region of Mato Grosso, Brazil. Disturbed and undisturbed soil samples were collected in three layers (0-0.05, 0.05-0.10 and 0.10-0.20 m). The CMI (CLI x CCI) showed higher $\mathrm{S}_{\mathrm{TOC}}$ possibly as the tillage depth decreased, because none of the tillage systems conserved $\mathrm{S}_{\text {TOC }}$ and $S_{L C}$ in the layers of 0-0.05 and 0.05-0.10 m, compared with the Native Cerrado, i.e., soil $\mathrm{C}$ conservation only occurred in the layer of $0.10-0.20 \mathrm{~m}$. Although the percentage of $\mathrm{S}_{\mathrm{LC}}$ in $\mathrm{S}_{\mathrm{TOC}}$ was lower, only $\mathrm{S}_{\mathrm{LC}}$ was correlated with soil chemical and physical attributes and, based on the multiple linear regression analysis, $\mathrm{S}_{\mathrm{LC}}$ was explained in $54 \%\left(\mathrm{R}^{2}\right)$ by the cation exchange capacity and soil micropores. Therefore, for monitoring purposes, the $\mathrm{S}_{\mathrm{LCestimated}}$ can be useful to evaluate soil $\mathrm{C}$ storage.
\end{abstract}

\section{Palavras-chave:}

conservação do solo rotação de culturas matéria orgânica do solo

\section{Estoques de carbono em Latossolo após trinta e oito anos sob diferentes sistemas de cultivo}

\section{R E S U M O}

A determinação do estoque de carbono do solo pode subsidiar discussões sobre manejos agropecuários. Objetivou-se determinar os estoques de carbono orgânico total $\left(\mathrm{E}_{\mathrm{COT}}\right)$ e lábil $\left(\mathrm{E}_{\mathrm{CL}}\right)$ além dos índices de labilidade (IL), de compartimento (ICC) e de manejo do carbono (IMC) e correlacioná-los com atributos químicos e físicos de um Latossolo Vermelho-Amarelo manejado por 38 anos em diferentes sistemas de cultivo em bioma Cerrado. Coletaram-se amostras deformadas e indeformadas de solo nas camadas de 0-0,05; 0,05-0,10 e 0,10-0,20 m. Verificou-se que: o IMC (IL x ICC) acusou maior $\mathrm{E}_{\mathrm{COT}}$ à medida que diminuiu possivelmente a profundidade de revolvimento do solo pois nas camadas de 0-0,05 e 0,05-0,10 m nenhum sistema de cultivo conservou os $\mathrm{E}_{\mathrm{COT}}$ e $\mathrm{E}_{\mathrm{CL}}$ comparado ao Cerrado nativo, isto é, apenas de 0,10-0,20 m ocorreu conservação do carbono no solo; embora a porcentagem do $\mathrm{E}_{\mathrm{CL}}$ sobre $\mathrm{o} \mathrm{E}_{\mathrm{COT}}$ fosse menor, apenas o $\mathrm{E}_{\mathrm{CL}}$ se correlacionou com atributos químicos e físicos do solo e, com base na análise de regressão linear múltipla, o $\mathrm{E}_{\mathrm{CL}}$ foi explicado em $54 \%\left(\mathrm{R}^{2}\right)$ pela capacidade de troca de cátions e os microporos do solo. Portanto, para fins de monitoramento a $\mathrm{E}_{\mathrm{CL} \text { estimada }}$ pode ser útil para avaliar a estocagem de carbono no solo. 


\section{INTRODUCTION}

There has been a general concern about water limitations and the conservation of non-renewable natural resources. Despite being a renewable resource, the soil is considered as one of the focuses of attention, since it can be degraded physically, chemically and biologically, depending on use and management. In addition, it is known that in the process of substitution of native environments for agricultural activities, changes in the soil are inevitable and, depending on management and the local edaphoclimatic potential, if not adequate for a certain production system, the soil can be economically and environmentally hampered (Silva \& Mendonça, 2007). Additionally, there are problems related to the few options of economically viable, large-scale crops for crop rotation in the Cerrado region.

Among the attributes of the soil, which is sensitive to variations in use and management, soil organic matter (SOM) has been the most studied one, because there is a close dependence between various chemical, physical and biological processes in terrestrial ecosystems (Strickland \& Rousk, 2010). Many authors have pointed out its importance for soil quality, because it influences, among other properties: aggregate stability and soil structure (Hickmann et al. 2012); water infiltration rate and soil water holding capacity (Rawls et al., 2003); biological activity (Matoso et al., 2012); cation exchange capacity, nutrient cycling and availability to plants (Silva \& Mendonça, 2007); ion complexation (Botero et al., 2010); and the release of $\mathrm{CO}_{2}$ and other gases (Lal \& Bruce, 1999).

SOM comprises plant residues at different decomposition stages, besides edaphic organisms involved in this process, and can be associated with mineral matter in different proportions (Santos et al., 2013). It is mainly composed of carbon (C), which is the reason why it is expressed in content of soil organic $\mathrm{C}$ $\left(\mathrm{g} \mathrm{kg}^{-1}\right)$ or mass per unit area $\left(\mathrm{g} \mathrm{m}^{-2}\right)$ for a certain soil layer. However, its mineralization and release of gas in the form of $\mathrm{CO}_{2}$ vary according to the degree of alterations caused in the biophysical environment of the soil (Izaurralde \& Cerri, 2006). Therefore, $C$ can be useful as an indicator of changes in the amount ( $\mathrm{C}$ stock) and quality (labile and non-labile $\mathrm{C}$ fractions) of organic matter in cultivated soils.

In addition, while the mineralization of labile constituents occurs in a few weeks or months, $\mathrm{C}$ in the non-labile fraction is more stable and refers to humic substances and macromolecules of difficult decomposition by microorganisms, showing a slower cycling compared with $\mathrm{C}_{\text {labile }}$. Thus, SOM fractionation based on the decomposition rate can allow better understanding of its dynamic in the soil (Blair et al., 1995; Silva \& Mendonça, 2007). Therefore, the evaluation of SOM amount and quality can subsidize discussions on the continuity of a management, revealing its strong and weak points that can enhance the researches on the importance of biodiversity in production systems, besides contributing to the readjustment of cultural practices that aim at the homeostasis of the production system.

Given the above, this study aimed to evaluate the stocks of $\mathrm{C}_{\text {total }}$ and $\mathrm{C}_{\text {labile }}$ of a Red Yellow Latosol managed for 38 years with different tillage systems, in the Cerrado region of Mato Grosso, Brazil.

\section{Material AND Methods}

The study was carried out in the municipality of Campo Verde-MT, Brazil (BR 070, km 349), at the geographical coordinates of $15^{\circ} 28^{\prime} 41.79^{\prime \prime} \mathrm{S}$ and $54^{\circ} 54^{\prime} 17.20^{\prime \prime} \mathrm{W}$, in the Mourão Farm, at $694 \mathrm{~m}$ of altitude. The climate in the region is Aw, according to Köppen's classification. Rainfall regime is well defined, with a dry period from May to September and a rainy period from October to April. The mean annual precipitation is $1,670 \mathrm{~mm}$ and the mean annual temperature is $24^{\circ} \mathrm{C}$. The soil in the experimental area was classified as typical dystrophic Red Yellow Latosol, with clayey texture and moderate texture in the A horizon, located in a Semi-deciduous Tropical Cerrado, on a flat relief (Santos et al., 2013). The tillage history of the evaluated soil is described in Table 1.

In May 2010, in each soil tillage system (environments), a $300 \times 300 \mathrm{~m}$ central area was delimited and six soil pits were longitudinally dug, in the form of steps, for the collection of disturbed and undisturbed soil samples in the layers of 0-0.05, 0.05-0.10 and 0.10-0.20 m. Undisturbed soil samples were collected using a Kopeck sampler for the determination of microporosity and soil density (Donagema et al., 2011). In the disturbed soil samples, the following parameters were determined: particle density, for the calculation of total porosity and then macroporosity $(\mathrm{Ma}=\mathrm{TP}-\mathrm{Mi})$; the percentage of sand, silt and clay, through the pipette method using a reciprocal shaker at 100 RPM (revolutions per minute) for $16 \mathrm{~h}$ to accelerate particle dispersion; contents of $\mathrm{P}$ and $\mathrm{K}$ extracted with $0.05 \mathrm{~mol} \mathrm{~L}^{-1} \mathrm{HCl}+0.0125 \mathrm{~mol} \mathrm{~L}^{-1} \mathrm{H}_{2} \mathrm{SO}_{4}$ and $\mathrm{Ca}, \mathrm{Mg}$ and $\mathrm{Al}$ extracted with $0.1 \mathrm{~mol} \mathrm{~L}^{-1} \mathrm{KCl} ; \mathrm{pH}$ in water and $\mathrm{CaCl}_{2}$ (Donagema et al., 2011); content of total organic C (Yeomans \& Bremner, 1988); content of labile organic C through oxidation with $\mathrm{KMnO}_{4}\left(333 \mathrm{mmol} \mathrm{L}^{-1}\right)$, according to the methodology described in Blair et al. (1995) and modified by Shang \& Tiessen (1997); non-labile C, equivalent to the C not oxidized by $\mathrm{KMnO}_{4}$, determined by difference, considering the total organic C.

The total $\mathrm{C}$ stock was calculated for each management system, according to Eq. 1, which was then standardized with the values of soil density of the Native Cerrado, the control area, for each evaluated soil layer, according to Fernandes \& Fernandes (2013), Eq. 2:

$$
\begin{gathered}
\mathrm{S}_{\mathrm{TOC}}=\frac{\mathrm{TOC} \cdot \mathrm{Ds} \cdot \mathrm{H}}{10} \\
\mathrm{~S}_{\mathrm{TOC}}=\frac{\mathrm{TOC} \cdot \mathrm{Ds} \cdot\left(\frac{\mathrm{Ds}_{\text {control }}}{\mathrm{Ds}}\right) \cdot \mathrm{H}}{10}
\end{gathered}
$$

where:

$\mathrm{S}_{\text {тос }}$ - stock of total carbon in the evaluated soil layer, $\mathrm{Mg} \mathrm{ha}^{-1}$;

TOC - content of total organic carbon, $\mathrm{g} \mathrm{kg}^{-1}$;

Ds - soil density, $\mathrm{Mg} \mathrm{dm}^{-3}$; and 
Table 1 . Soil use systems and their respective tillage histories

\begin{tabular}{|c|c|c|}
\hline Soil use & Symbol & Soil tillage history \\
\hline $\begin{array}{l}\text { Native } \\
\text { Cerrado }\end{array}$ & NC & $\begin{array}{l}\text { Fragment of Cerrado (strict sense), without signs of anthropic disturbance, characterized by the presence of small, twisted } \\
\text { trees and grasses covering the soil. This area was considered as a control for the comparison with the tillage systems. }\end{array}$ \\
\hline $\begin{array}{l}\text { Minimum } \\
\text { tillage I }\end{array}$ & MTI & $\begin{array}{l}\text { The Cerrado was deforested in } 1977 \text {, with subsequent cultivation of rice/soybean for } 3 \text { years under conventional tillage } \\
\text { and, until the } 1999 / 00 \text { season, soybean/corn was cultivated in rotation under conventional tillage, disturbing the soil with } \\
\text { heavy harrowing with discs of } 32 \text { " every } 3 \text { years. In } 2000 / 02 \text {, cotton was cultivated, followed by gypsum application, two } \\
\text { harrowings ( } 32 \text { ') and seeding of millet in the off-season. In } 2002 / 03 \text {, gypsum was applied and the soil was prepared with } \\
\text { scarification until } 0.30 \text { m, two harrowings ( } 32 \text { "), and soybean and corn were sown in the off-season. In } 2003 / 04 \text {, gypsum } \\
\text { was applied broadcast and cotton was cultivated on corn residues with later destruction of stumps, combining mechanical } \\
\text { mowing and a light harrowing to incorporate plant residues. In } 2004 / 07 \text {, gypsum was applied, a leveling harrow was used } \\
\text { and soybean and millet were cultivated in the off-season. In } 2007 / 08 \text {, there were gypsum application, two harrowings } \\
\text { (32'), scarification until } 0.30 \mathrm{~m} \text { and cultivation of soybean and corn. In } 2008 / 10 \text {, gypsum was applied, a light harrow } \\
\text { was used and soybean and corn were cultivated in the off-season. All the fertilizations were performed in the seeding row } \\
\text { and followed the technical recommendations for the crops, as also occurred in the systems MT II and MT II, which are } \\
\text { described below. Therefore, only in the last two crop seasons there was lower disturbance on soil surface, with a light } \\
\text { harrowing before soybean sowing. }\end{array}$ \\
\hline $\begin{array}{l}\text { Minimum } \\
\text { tillage II }\end{array}$ & MT II & $\begin{array}{l}\text { The Cerrado was deforested in } 1977 \text {, with subsequent cultivation of rice/soybean for } 3 \text { years under conventional tillage and, } \\
\text { until the } 1999 / 00 \text { season, soybean/corn was cultivated in rotation under conventional tillage, disturbing the soil with heavy } \\
\text { harrowing with discs of } 32 " \text { every } 3 \text { years. In } 2000 / 02 \text {, millet was cultivated, followed by gypsum application, two harrowings } \\
\text { (32") and sowing of cotton. In } 2002 / 03 \text {, gypsum was applied and soybean and corn were cultivated in the off-season. In } \\
2003 / 04 \text {, cotton was sown on corn residues. In } 2004 / 06 \text {, the soil was prepared with two harrowings (32"), and millet and } \\
\text { cotton were sown in rotation. Then, gypsum was applied and the stumps were destroyed, combining a mechanical mowing } \\
\text { with a harrowing to incorporate plant residues. In } 2006 / 07 \text {, the soil was scarified until } 0.30 \text { m and millet and cotton were } \\
\text { cultivated in rotation, with later destruction of the stumps. In } 2007 / 08 \text {, millet and cotton were sown in rotation, with later } \\
\text { destruction of the stumps. In 2008/09, limestone was applied in association with gypsum and soybean and corn were } \\
\text { cultivated in the off-season. In 2009/10, cotton was sown on corn residues. Therefore, soil disturbance was more frequent } \\
\text { in this tillage system than in the previous one, MT I. }\end{array}$ \\
\hline $\begin{array}{l}\text { Minimum } \\
\text { tillage III }\end{array}$ & MT III & $\begin{array}{l}\text { The Cerrado was deforested in } 1976 \text {, with subsequent cultivation of rice/soybean for } 3 \text { years under conventional tillage and, } \\
\text { until the } 1999 / 00 \text { season, soybean/corn was cultivated in rotation under conventional tillage, disturbing the soil with heavy } \\
\text { harrowing with discs of } 32 \text { " every } 3 \text { years. In } 2000 / 04 \text {, cotton was cultivated, followed by corn, and limestone was applied } \\
\text { before the } 2001 / 02 \text { season and incorporated with two harrowings (32"). Cotton stumps were destroyed combining } \\
\text { mechanical mowing and harrowing to incorporate plant residues. In } 2004 / 05 \text {, the soil was subjected to two harrowings ( } 32 ") \text {, } \\
\text { subsoiled and sown with soybean followed by corn, with later gypsum application. In } 2005 / 06 \text {, cotton was cultivated on corn } \\
\text { residues. In } 2006 / 10 \text {, there were crop rotations with soybean/corn, corn/cotton and soybean/cotton, respectively. Therefore, } \\
\text { the soil was harrowed not only when cotton was cultivated, although a heavy harrow was used just at the end of its cycle to } \\
\text { destroy the stumps. Thus, soil disturbance was more frequent in this system than in the previous ones (MT I and MT II), and } \\
\text { millet was not cultivated. }\end{array}$ \\
\hline $\begin{array}{l}\text { Intensive } \\
\text { pasture }\end{array}$ & IP & $\begin{array}{l}\text { The Cerrado was deforested in } 1978 \text { and rice was cultivated from } 1978 \text { to } 1980 \text {. In } 1981 \text {, Brachiaria brizantha cv. Marandu } \\
\text { was planted and weed control was manually performed every } 2 \text { years under intensive management with Nelore cattle for } \\
\text { fattening, with mean capacity of } 7-9 \text { A.U. ha-1, without animal rotation. Since } 1997 \text {, every } 3 \text { years, the soil has been chemically } \\
\text { corrected with the dose of } 1,5 \mathrm{Mg} \mathrm{ha}^{-1} \text { of dolomitic limestone, plus a fertilization with } 100 \mathrm{~kg} \mathrm{~h}^{-1} \text { of single superphosphate } \\
\text { as top-dressing. Since } 2003 \text {, between March and April, } 10 \text { tons of cotton hull have been applied. Gypsum was applied } \\
\text { broadcast in 2008, in the dose of } 500 \mathrm{~kg} \mathrm{ha}^{-1} \text {. }\end{array}$ \\
\hline
\end{tabular}

$\mathrm{H} \quad$ - thickness of the evaluated soil layer, $\mathrm{cm}$.

Then, based on the quantifications of $\mathrm{C}$ forms in the soil, the following parameters were calculated: (i) stock of labile C $\left(\mathrm{S}_{\mathrm{LC}}, \mathrm{Mg} \mathrm{ha}^{-1}\right)$, Eq. 3; (ii) C lability index (CLI), Eq. 4; (iii) C compartment index (CCI), Eq. 5 and (iv) $\mathrm{C}$ management index (CMI), according to Blair et al. (1995), Eq. 6:

$$
\begin{gathered}
\mathrm{S}_{\mathrm{LC}}=\mathrm{S}_{\mathrm{TOC}}-\mathrm{S}_{\mathrm{NLC}} \\
\mathrm{CLI}=\frac{\mathrm{SLC}_{\text {cultivated }}}{\mathrm{SLC}_{\text {control }}} \\
\mathrm{CCI}=\frac{\mathrm{STOC}_{\text {cultivated }}}{\mathrm{STOC}_{\text {control }}} \\
\mathrm{CMI}=(\mathrm{CCI} \cdot \mathrm{CLI}) \cdot 100
\end{gathered}
$$

All data showed normal distribution according to the Shapiro-Wilk test $(\mathrm{P}>0.05)$. Thus, the analysis of variance was performed by $\mathrm{F}$ test (Fischer) and treatment means were compared by Tukey test $(\mathrm{P}<0.05)$ for $\mathrm{S}_{\mathrm{TOC}}$ and $\mathrm{S}_{\mathrm{LC}}$. Then, bivariate correlation analysis was performed using Pearson coefficient and t-test $(\alpha=0.05)$, between the analyzed variables in order to define the regression variable, i.e., the independent variable(s) that best predict(s) the dependent variable, which was the soil carbon stock. For this, a multiple linear regression analysis (Best Subset Regression) was performed, which estimates all the probable regression models with one, two, three and $\mathrm{n}$ independent variables, identifying the model(s) with the best combinations capable of predicting the dependent variable using the program SigmaPlot Versão 12.5, Eq. 7:

$$
\mathrm{Y}_{\mathrm{i}}=\beta_{0}+\beta_{1} \mathrm{X}_{\mathrm{i} 1}+\beta_{2} \mathrm{X}_{\mathrm{i} 2}+\ldots+\beta_{\mathrm{p}-1} \mathrm{X}_{\mathrm{i}, \mathrm{p}-1}+\varepsilon_{\mathrm{i}}
$$

where:

$\mathrm{Y}_{\mathrm{i}} \quad$ - response in the $\mathrm{i}$-th test $\mathrm{X}_{\mathrm{i} 1}, \mathrm{X}_{\mathrm{i} 2}$; and

$\mathrm{X}_{\mathrm{i}, \mathrm{p}-1}$ - values of the $\mathrm{n}$ predicting variables in the $\mathrm{i}$-th test.

The parameters of the model are $\beta_{0}, \beta_{1}, \beta_{2}, \beta_{2 \mathrm{p}-1}$ and the error term is $\varepsilon_{\mathrm{i}}$, which are independent with distribution $\mathrm{N}\left(0, \sigma^{2}\right)$. 
$\mathrm{Y}_{\mathrm{i}}$ is the dependent metric variable "carbon stock" $\left(\mathrm{Mg} \mathrm{ha}^{-1}\right)$ and $\mathrm{X}_{1}, \mathrm{X}_{2}, \mathrm{X}_{3}, \ldots, \mathrm{X}_{\mathrm{n}}$ are independent metric variables of soil chemical and physical attributes.

The criteria used to select the best multiple linear regression model were the adjusted coefficient of determination $\left(\mathrm{R}^{2}\right.$ Adj.) and the significance level of the beta coefficient $(\beta)$, a standardized regression coefficient that allows comparing the prediction capacity of each independent variable (Hair Júnior et al., 2009).

\section{Results AND Discussion}

In the layers of 0-0.05 and 0.05-0.10 m, the mean value of the stock of total organic carbon $\left(\mathrm{S}_{\mathrm{TOC}}\right)$ between the Native Cerrado (NC) and the Intensive Pasture (IP) were equal, while a reduction was observed for the other tillage systems. In the layer of $0.10-0.20 \mathrm{~m}$, the anthropized systems stocked more $C$ than the Native Cerrado (Figure 1). It is known that the impacts of mechanical operations tend to be more pronounced in the superficial soil layer and, therefore, soil uses that prioritize the absence of disturbance can conserve more organic $\mathrm{C}$ in surface, as verified for the pasture. This beneficial effect of the lack of soil disturbance has been reported in
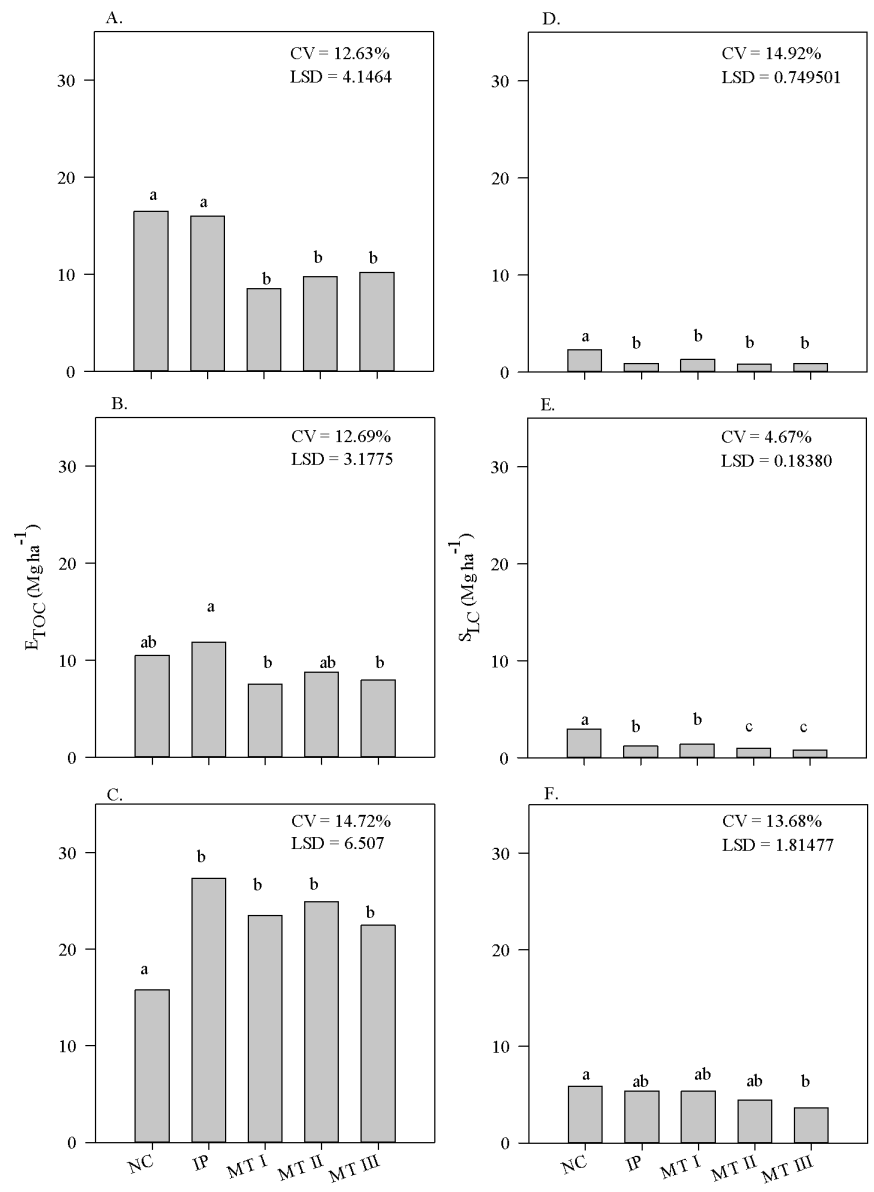

Soi tillage systems

Different letters indicate differences between systems by Tukey test $(P<0.05)$; $L S D=$ least significant difference; $\mathrm{CV}=$ coefficient of variation

Figure 1. Stocks of total organic carbon $\left(\mathrm{S}_{\text {TоC }}\right)$ in the layers of 0-0.05 (A), 0.05-0.10 (B) and 0.10-0.20 m (C) and labile carbon $\left(\mathrm{S}_{\mathrm{LC}}\right)$ in the layers of 0-0.05 (D), 0.05-0.10 (E) and $0.10-0.20 \mathrm{~m}(\mathrm{~F})$, under different management systems (Table 1) other edaphoclimatic conditions. Leite et al. (2010) observed progressive increment of $\mathrm{S}_{\text {ТоС }}$ over time, under no-tillage of 2, 4 and 6 years; even higher than under Cerrado native forest and under conventional tillage, in a Red Yellow Latosol.

The beneficial effect of the lack of soil disturbace is corroborated by other studies, which show higher conservation of the soil under pasture, no-tillage and minimum tillage, compared with the conventional tillage (Hickmann et al., 2012; Matoso et al., 2012). According to Leite et al. (2013), pasture is important for intercropping, because it increases soil fertility levels and C stocks, favoring the improvement of soil quality under Cerrado conditions. Therefore, the lower the frequency of soil disturbance and the maturity of the conservational tillage, the higher is the probability of organic $\mathrm{C}$ storage. Thus, the increase of total C stock in the layer of $0.10-0.20 \mathrm{~m}$ for the four evaluated minimum cultivation systems was possibly due to the lower soil disturbance by mechanical operations in this layer (Figure 1C). In addition, the removal of chemical (limestone and gypsum applications) and physical (subsoiling) impediments, according to Arantes et al. (2007) and Pupin et al. (2009), respectively, favors root growth in subsurface and, consequently, $\mathrm{C}$ accumulation.

As to the stock of labile $\mathrm{C}\left(\mathrm{S}_{\mathrm{LC}}\right)$, its participation in $\mathrm{S}_{\mathrm{TOC}}$ was low. $S_{L C}$ mean values in the layers of 0-0.05 and 0.05-0.10 $\mathrm{m}$ were higher under Native Cerrado. In the layer of 0.10-0.20 $\mathrm{m}$, except for the Minimum Tillage III (MT III), which showed lower $\mathrm{S}_{\mathrm{LC}}$, the other tillage systems showed intermediate $\mathrm{C}$ stocks compared with the Cerrado. The soil disturbance in MT III was more frequent than in MT I and II, and millet was not cultivated independently; however, regardless of the evaluated management system, there were higher stocks of total organic C (Figure 1C) and labile $\mathrm{C}$ (Figure $1 \mathrm{~F}$ ) in the deepest layer $(0.10-0.20 \mathrm{~m})$, compared with the more superficial ones (0-0.05 and 0.05-0.10 m).

Therefore, the results are consistent with other studies on $\mathrm{C}$ stock, because the inverse of $\mathrm{S}_{\mathrm{LC}}$ is characterized by the stock of non-labile $\mathrm{C}\left(\mathrm{S}_{\mathrm{NLC}}\right)$, proportionally higher than $\mathrm{S}_{\mathrm{LC}}$ (Figure $1 \mathrm{C}$, $1 \mathrm{D}$ and $1 \mathrm{E})$. While labile $\mathrm{C}$ is composed of plant and animal residues in decomposition and thus an important source of labile nutrients to plants, the non-labile $\mathrm{C}$ is composed of organic residues in high degree of decomposition and specific density; thus, the heavy fraction is important for the sequestration of C- $\mathrm{CO}_{2(\mathrm{~g})}$ (Blair et al., 1995; Silva \& Mendonça, 2007).

Since the non-labile fraction is dependent on the continuous supply of the labile fraction, it is possible to infer about the equilibrium between these fractions promoted by a certain management, due to changes in quality and quantity of the supplied organic matter. These results can be important to rethink the current management and plan techniques capable of reducing the losses of soil organic matter. The highest values of C lability index (CLI) and C compartment index (CCI) were observed in the layer of $0.10-0.20 \mathrm{~m}$ (Figure 2A, 2B); therefore, among the evaluated layers, the layer of $0.10-0.20 \mathrm{~m}$ was the most similar to the Native Cerrado with respect to $\mathrm{C}$ stock. In addition, the multiplication of CLI by CCI results in the $\mathrm{C}$ management index (CMI) and, while an increase of $66 \%$ was observed for the Intensive Pasture (IP), $41 \%$ for Minimum 

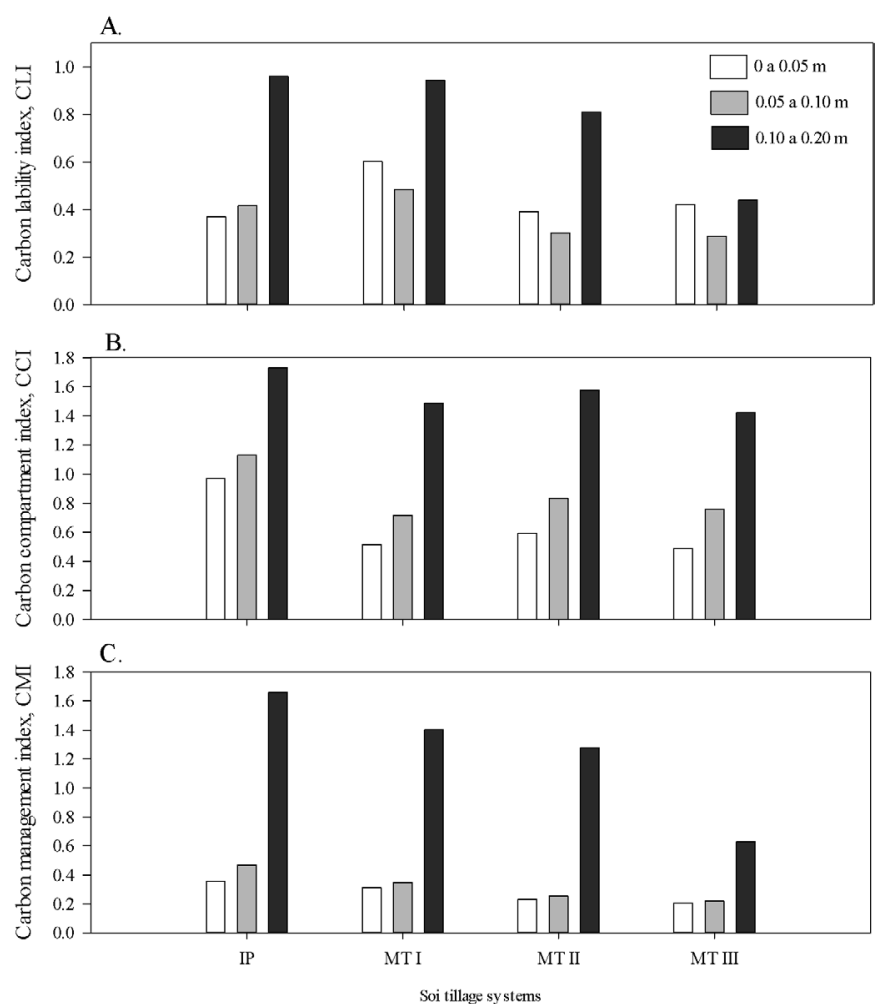

Figure 2. Indices of carbon lability (A); carbon compartment (B) and carbon management $(\mathrm{C})$ in different management systems: intensive pasture (IP), minimum tillage I (MT I); minimum tillage II (MT II) and minimum tillage III (MT III)

Tillage I, 28\% for Minimum Tillage II, there was a reduction of approximately $37 \%$ for the Minimum Tillage III. According to Blair et al. (1995), there is no ideal value for CMI, but this index provides a sensitive measurement of soil $\mathrm{C}$ dynamics in relation to a more stable reference system, indicating whether a certain management system is degrading or conserving soil C. Therefore, in the layers of $0-0.5$ and $0.5-0.10 \mathrm{~m}$, none of the management systems was able to conserve $\mathrm{C}$ stocks, compared with the Native Cerrado, only IP, MT I and MT II in the layer of $0.10-0.20 \mathrm{~m}$.

In the correlation of the stocks of total $\mathrm{C}\left(\mathrm{S}_{\mathrm{TOC}}\right)$, labile $\mathrm{C}$ $\left(\mathrm{S}_{\mathrm{LC}}\right)$ and non-labile $\mathrm{C}\left(\mathrm{S}_{\mathrm{NLC}}\right)$ with soil chemical and physical attributes, $\mathrm{S}_{\mathrm{TOC}}$ was positively correlated with $\mathrm{S}_{\mathrm{LC}}$ and $\mathrm{S}_{\mathrm{NLC}}$ (Table 2 ). Although $S_{\mathrm{NLC}}$ was not correlated with any variable, $S_{\mathrm{LC}}$ was correlated with most of the analyzed chemical and physical attributes (Table 2). According to Blair et al. (1995), although labile $\mathrm{C}$ degrades faster than non-labile $\mathrm{C}$, it is restored more rapidly and only then it will be a more sensitive indicator to evaluate C dynamics. According to Silva et al. (2011), although the TOC analysis is sensitive to detect differences between soil management systems, the degree of alteration is higher in labile fractions of SOM; for these reasons, $S_{L C}$ can be used as an indicator to evaluate soil tillage systems with respect to the stock of soil organic carbon.
Table 2. Correlation of the stocks of total organic carbon $\left(\mathrm{S}_{\mathrm{TOC}}\right)$, labile carbon $\left(\mathrm{S}_{\mathrm{LC}}\right)$ and non-labile carbon $\left(\mathrm{S}_{\mathrm{NLC}}\right)$ with soil chemical and physical attributes

\begin{tabular}{|c|c|c|c|}
\hline & $S_{\text {TOC }}$ & $S_{L C}$ & $S_{\text {NLC }}$ \\
\hline $\mathrm{S}_{\text {TOC, }} \mathrm{Mg} \mathrm{ha}^{-1}$ & 1 & & \\
\hline $\mathrm{S}_{\mathrm{LC}}, \mathrm{Mg} \mathrm{ha}^{-1}$ & $0.72^{\star \star \star(1)}$ & 1 & \\
\hline $\mathrm{S}_{\mathrm{NLC}}, \mathrm{Mg} \mathrm{ha}^{-1}$ & $0.98^{\star \star \star}$ & $0.55^{\star \star \star}$ & 1 \\
\hline $\mathrm{pH}, \mathrm{H} 2 \mathrm{O}$ & $0.13^{\mathrm{ns}}$ & $-0.28^{n s}$ & $0.25^{\mathrm{ns}}$ \\
\hline $\mathrm{pH}, \mathrm{CaCl}_{2}$ & $0.04^{\text {ns }}$ & $-0.46^{* *}$ & $0.17^{\mathrm{ns}}$ \\
\hline $\mathrm{P}, \mathrm{mg} \mathrm{dm}^{-3}$ & $-0.18^{\mathrm{ns}}$ & $-0.47^{\star \star}$ & $-0.07^{\mathrm{ns}}$ \\
\hline $\mathrm{K}, \mathrm{cmol}_{\mathrm{c}} \mathrm{dm}^{-3}$ & $0.09^{\text {ns }}$ & $-0.27^{\mathrm{ns}}$ & $0.19^{\mathrm{ns}}$ \\
\hline $\mathrm{Ca}, \mathrm{cmol}_{\mathrm{c}} \mathrm{dm}^{-3}$ & $-0.14^{\text {ns }}$ & $-0.57^{* *}$ & $0.01^{\mathrm{ns}}$ \\
\hline $\mathrm{Mg}, \mathrm{cmol}_{\mathrm{c}} \mathrm{dm}^{-3}$ & $-0.03^{\text {ns }}$ & $-0.48^{\star \star}$ & $0.12^{\mathrm{ns}}$ \\
\hline $\mathrm{Al}, \mathrm{cmol}_{\mathrm{C}} \mathrm{dm}^{-3}$ & $0.06^{\mathrm{ns}}$ & $0.28^{\mathrm{ns}}$ & $-0.02^{\mathrm{ns}}$ \\
\hline $\mathrm{H}, \mathrm{Cmol}_{\mathrm{c}} \mathrm{dm}^{-3}$ & $-0.09^{\text {ns }}$ & $-0.04^{\mathrm{ns}}$ & $-0.09^{n s}$ \\
\hline $\mathrm{SB}, \mathrm{cmol}_{\mathrm{c}} \mathrm{dm}^{-3}$ & $-0.09^{n s}$ & $-0.55^{\star \star}$ & $0.06^{\mathrm{ns}}$ \\
\hline $\mathrm{CEC}, \mathrm{cmol}_{\mathrm{c}} \mathrm{dm}^{-3}$ & $-0.15^{\mathrm{ns}}$ & $-0.60 * \star \star$ & $0.01^{\mathrm{ns}}$ \\
\hline V (\%) & $-0.05^{\mathrm{ns}}$ & $-0.48^{\star \star}$ & $0.09^{\text {ns }}$ \\
\hline Sand, $\mathrm{g} \mathrm{kg}^{-1}$ & $0.01^{\mathrm{ns}}$ & $0.29 *$ & $-0.08^{\mathrm{ns}}$ \\
\hline Silt, $\mathrm{g} \mathrm{kg}^{-1}$ & $0.03^{\mathrm{ns}}$ & $-0.07^{\text {ns }}$ & $0.06^{\mathrm{ns}}$ \\
\hline Clay, $\mathrm{g} \mathrm{kg}^{-1}$ & $-0.02^{\mathrm{ns}}$ & $-0.30 * \star$ & $0.07^{\mathrm{ns}}$ \\
\hline Soil density, $\mathrm{Mg} \mathrm{m}^{-3}$ & $0.06^{\mathrm{ns}}$ & $0.15^{\mathrm{ns}}$ & $0.02^{\mathrm{ns}}$ \\
\hline Macroporosity, $\mathrm{m}^{3} \mathrm{~m}^{-3}$ & $0.12^{\mathrm{ns}}$ & $0.40^{\star \star}$ & $0.02^{\mathrm{ns}}$ \\
\hline Microporosity, $\mathrm{m}^{3} \mathrm{~m}^{-3}$ & $-0.10^{\mathrm{ns}}$ & $-0.47^{* *}$ & $0.03^{\mathrm{ns}}$ \\
\hline Total porosity, $\mathrm{m}^{3} \mathrm{~m}^{-3}$ & $0.00^{\mathrm{ns}}$ & $-0.24^{n s}$ & $0.07^{\mathrm{ns}}$ \\
\hline
\end{tabular}

Since $\mathrm{S}_{\mathrm{LC}}$ was correlated with $\mathrm{S}_{\mathrm{NLC}}$ and the latter was positively correlated with $\mathrm{S}_{\text {TOC }}$, the former was selected as the independent variable, applying the Best-Subset Regression analysis to define the independent variable(s) that best predict(s) $\mathrm{S}_{\mathrm{LC}}$. Thus, it was verified that the chemical attributes were negatively correlated with $\mathrm{S}_{\mathrm{LC}}$ and that cation exchange capacity (CEC) showed the highest Pearson coefficient. According to Hair Júnior et al. (2009), the occurrence of implicit collinearity must be avoided, because it decreases the unique variance provided by each predicting variable. Thus, CEC was selected among the chemical attributes, because it was correlated with $\mathrm{pH}, \mathrm{P}, \mathrm{Ca}, \mathrm{Mg}, \mathrm{SB}$ and $\mathrm{V} \%(\mathrm{P}<0.05)$.

Among soil physical attributes, the data of sand, clay, macropores and micropores were the ones correlated with $\mathrm{S}_{\mathrm{LC}}$, but since micropores were correlated with sand, the variables clay and macropores $(P<0.05)$ were selected, because they showed the highest Pearson coefficients, and the $\mathrm{S}_{\mathrm{LC}}$ was explained in almost $54 \%\left(\mathrm{R}^{2}\right)$ based on the multiple linear model (Table 3 ). The assumptions inherent to the regression analysis, i.e., linearity based on Pearson coefficient of $\approx 74 \%$ and residual independence $(\mathrm{P}>0.05)$ were maintained. In addition, the statistical model was significant by $\mathrm{F}$ test, with intercept and coefficient different from zero and estimate standard error of at most $0.962 \mathrm{Mg} \mathrm{ha}^{-1}$. Thus, it is possible to estimate $\mathrm{S}_{\mathrm{LC}}$ as a function of the cation exchange capacity and the volume of micropores in the soil (Table 3 ).

In the comparison between data pairs of $S_{\text {LCestimated }}$ and $S_{\text {LCobserved }}$, it is possible to visualize the equivalence of $S_{\text {LCestimated }}$

Table 3. Regression between data pairs of labile carbon stock $\left(\mathrm{S}_{\mathrm{LC}}\right)$ versus cation exchange capacity (CEC) and soil micropores (Mi)

\begin{tabular}{|c|c|c|c|c|c|c|c|c|c|c|}
\hline \multirow{2}{*}{$\begin{array}{l}\text { Intercept }^{* \star *} \\
\text { y0 (1) }\end{array}$} & \multicolumn{2}{|c|}{ Coefficients $^{* * *}$} & \multirow{2}{*}{$\mathbf{N}^{(1)}$} & \multirow{2}{*}{$r^{(2)}$} & \multirow{2}{*}{$R^{2(3)}$} & \multirow{2}{*}{$\begin{array}{c}\mathbf{P} \\
\mathrm{F} \text { Test }\end{array}$} & \multirow{2}{*}{$\begin{array}{c}\text { ESE } \\
\left(\mathrm{Mg} \mathrm{ha}^{-1}\right)^{(4)}\end{array}$} & \multirow{2}{*}{ TRN ${ }^{(5)}$} & \multicolumn{2}{|c|}{ Calibration $\left(\mathrm{Mg} \mathrm{ha}^{-1}\right)$} \\
\hline & CEC & Mi & & & & & & & Minimum & Maximum \\
\hline 11.252 & -0.706 & -0.117 & 45 & 0.732 & 0.536 & $<0.001$ & 0.962 & 0.152 & 0.7041 & 6.7579 \\
\hline
\end{tabular}

(1) $\mathrm{N}$ - Number of data pairs used in the adjustment; (2) $r$ - Pearson coefficient $(P<0.0001)$; ${ }^{(3)} \mathrm{R}^{2}$ - Coefficient of determination; (4) ESE - Estimate standard error; (5) TRN - Test of residual normality through Kolmogorov-Smirnov with correction of Lilliefors $(P>0.05) ;{ }^{* * *}(\mathrm{P}<0.0001)$ : Significant at 0.05 probability level by t-test 
based on the bisector $(1: 1)$; therefore, an intermediate agreement was observed in the estimate of $S_{L \text { Cobserved }}$ by $\mathrm{S}_{\text {LCestimated }}$ based on the angular coefficient, which was equal to 0.536 (Figure $3 \mathrm{~A}$ ). Thus, the agreement would only be perfect if the angular coefficient were equal to one (1), consistent with the identity line (1:1). However, given the agreement between $S_{\text {LCestimated }}$ and $S_{\text {LCobserved }}$ through the Bland-Altman method, which evaluates the agreement between two variables, according to Ramos et al. (2014), it was possible to verify that the bias was not different from zero and, statistically, it means a valid agreement. Thus, there is no tendency in the data around the zero value, because the expected behavior is a random distribution of the differences around the mean of the methods (Figure 3B).

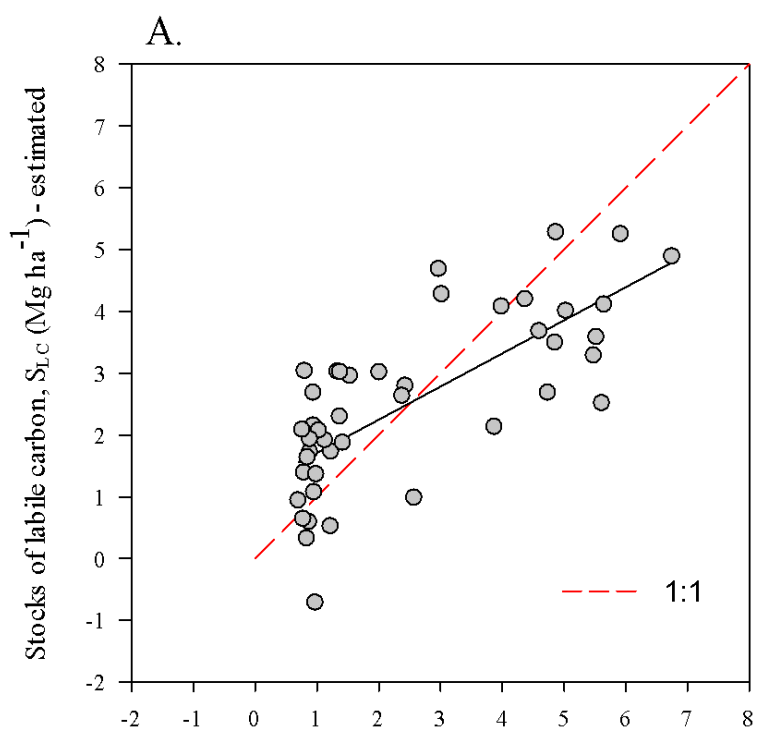

Stocks of labile carbon, $\mathrm{S}_{\mathrm{LC}}\left(\mathrm{Mg} \mathrm{ha}^{-1}\right)$ - observed B.

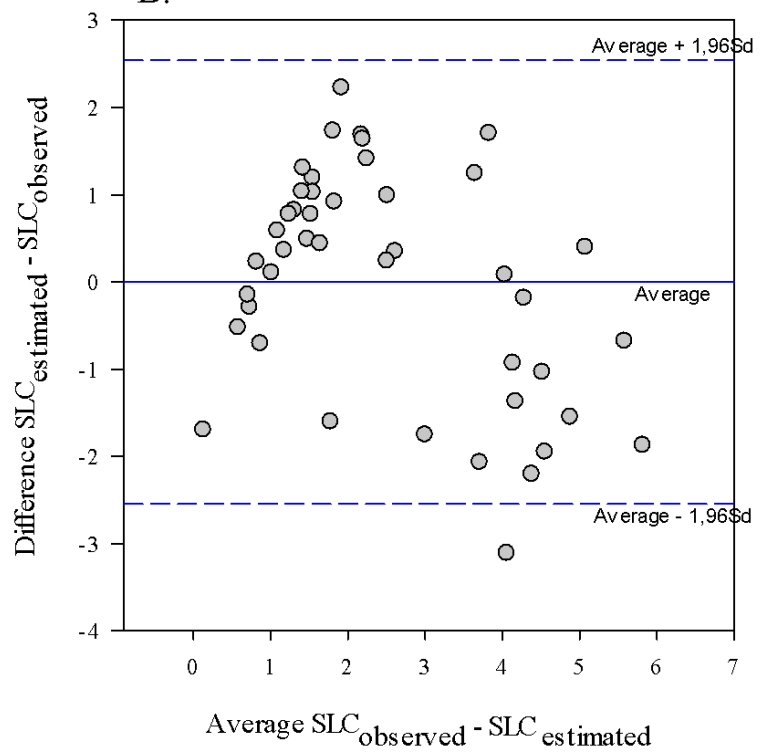

Figure 3. Comparison through the bisector between the observed $\mathrm{S}_{\mathrm{LC}}$ data and $\mathrm{S}_{\mathrm{LC}}$ data estimated through the regression of $\mathrm{CEC}+\mathrm{Mi}, \mathrm{F}$ test $(\mathrm{P}<0.0001)$, KolmogorovSmirnov test for residual normality with correction of Lilliefors $(P=0.8757)(A)$ and analysis of residues through the Bland-Altman method $(B)$ : Bias $=-6.0558 E-17(P=$ 0.243 by t-test), standard deviation $=1.2984$
Therefore, although the $\mathrm{S}_{\text {LCobserved }}$ is averagely estimated by cation exchange capacity and soil micropores, for monitoring purposes, the $\mathrm{S}_{\text {LCestimated }}$ can be useful to evaluate soil C stocks.

\section{Conclusions}

1. In the layers of 0-0.05 and $0.05-0.10 \mathrm{~m}$, none of the management systems was able to conserve stocks of total carbon $\left(\mathrm{S}_{\mathrm{TOC}}\right)$ and labile carbon $\left(\mathrm{S}_{\mathrm{LC}}\right)$, compared with the Native Cerrado; however, in the layer of $0.10-0.20 \mathrm{~m}$, these carbon stocks were conserved in the Pasture and the Minimum Tillage systems I and II.

2. Although the percentage of $S_{\mathrm{LC}}$ in the $\mathrm{S}_{\mathrm{TOC}}$ was lower, only $\mathrm{S}_{\mathrm{LC}}$ was correlated with soil chemical and physical attributes.

3. Based on the multiple linear regression analysis, $\mathrm{S}_{\mathrm{LC}}$ was explained in $54 \%\left(\mathrm{R}^{2}\right)$ by the cation exchange capacity and soil micropores.

\section{Literature Cited}

Arantes, S. A. C. M.; Lavorenti, A.; Tornisielo, V. L. Efeito da calagem e do glifosato na atividade microbiana de diferentes classes de solo. Pesticidas: Revista de Ecotoxicologia e Meio Ambiente, v.17, p.19-28, 2007.

Blair, G. J.; Lefroy, R. D. B. E.; Lisle, L. Soil carbon fractions based on their degree of oxidation, and development of a carbon management index for agricultural systems. Australian Journal of Agricultural Research, v.46, p.1459-1466, 1995. http://dx.doi. org/10.1071/AR9951459

Botero, W. G.; Oliveira, L. C.; Rocha, J. C.; Rosa, A. H.; Santos, A. Peat humic substances enriched with nutrients for agricultural applications: Competition between nutrients and non-essential metals present in tropical soils. Journal of Hazardous Materials, v.177, p.307-311, 2010. http://dx.doi.org/10.1016/j.jhazmat.2009.12.033

Donagema, G. K.; Campos, D. V. B.; Calderano, S. B.; Teixeira, W. G.; Viana, J. H. M. (org.). Manual de métodos de análise de solo. 2.ed. Rio de Janeiro: Embrapa Solos, 2011. 230p.

Fernandes, F. A.; Fernandes, A. H. B. M. Atualização dos métodos de cálculo dos estoques de carbono do solo sob diferentes condições de manejo. Corumbá: Embrapa Pantanal, 2013. 5p. Comunicado Técnico, 95.

Hair Júnior, J. F.; Black, W. C.; Babin, B. J.; Anderson, R. E.; Tatham, R. L. Análise multivariada de dados. 6.ed. São Paulo: Bookman, 2009. 688p.

Hickmann, C.; Costa, L. M.; Schaefer, C. E. G. R.; Fernandes, R. B. A.; Andrade, C. L. T. Atributos físico-hídricos e carbono orgânico de um argissolo após 23 anos de diferentes manejos. Revista Caatinga, v.25, p.128-136, 2012.

Izaurralde, R. C.; Cerri, C. C. Organic matter management. Encyclopedia of Soil Science. New York: Dekker, 2006. p.1189-1195.

Lal, R.; Bruce, J. P. The potential of world cropland soils to sequester $\mathrm{C}$ and mitigate the greenhouse effect. Environmental Science \& Policy, v.2, p.177-185, 1999. http://dx.doi.org/10.1016/S14629011(99)00012-X

Leite, L. F. C.; Arruda, F. P.; Costa, C. N.; Ferreira, J. S.; Holanda Neto, M. R. Qualidade química do solo e dinâmica de carbono sob monocultivo e consórcio de macaúba e pastagem. Revista Brasileira de Engenharia Agrícola e Ambiental, v.17, p.1257-1263, 2013. http://dx.doi.org/10.1590/S1415-43662013001200002 
Leite, L. F. C.; Galvão, S. R. S.; Holanda Neto, M. R.; Araújo, F. S.; Iwata, B. F. Atributos químicos e estoques de carbono em Latossolo sob plantio direto no cerrado do Piauí. Revista Brasileira de Engenharia Agrícola e Ambiental, v.14, p.1273-1280, 2010. http:// dx.doi.org/10.1590/S1415-43662010001200004

Matoso, S. C. G.; Silva, A. N.; Fiorelli-Pereira, E. C.; Colleta, Q. P.; Maia, E. Frações de carbono e nitrogênio de um Latossolo Vermelho-Amarelo distrófico sob diferentes usos na Amazônia brasileira. Acta Amazônica, v.42, p.231-240, 2012. http://dx.doi. org/10.1590/S0044-59672012000200008

Pupin, B.; Freddi, O. S.; Nahas, E. Microbial alterations of the soil influenced by induced compaction. Revista Brasileira de Ciência do Solo, v.33, p.1207-1213, 2009. http://dx.doi.org/10.1590/S010006832009000500014

Ramos, F. T.; Pivetta, F.; Mato, V. A. T.; Seixas, G. B.; Campelo Júnior, J. H. Acurácia e calibração de uma sonda de capacitância em um Neossolo Quartzarênico cultivado com caju. Bioscience Journal, v.30, p.1631-1641, 2014.

Rawls, W. J.; Pachepsky, Y. A.; Ritchie, J. C.; Sobecki, T. M.; Bloodworth, $\mathrm{H}$. Effect of soil organic carbon on soil water retention. Geoderma, v,116, p.61-76, 2003.

Santos, H. G.; Jacomine, P. K. T.; Anjos, L. H. C.; Oliveira, V. A.; Lumbreras, J. F.; Coelho, M. R.; Almeida, J. A.; Cunha, T. J. F.; Oliveira, J. B. Sistema brasileiro de classificação do solo. 3.ed. Brasília: Embrapa Solos, 2013. 353p.
Shang, C.; Tiessen, H. Organic matter lability in a tropical Oxisol: Evidence from shifting cultivation, chemical oxidation, particle size, density, and magnetic fractionations. Soil Science, v.162, p.795-807, 1997. http://dx.doi.org/10.1097/00010694-19971100000004

Silva, E. F.; Marchetti, M. E.; Mercante, F. M.; Ferreira, A. K. T.; Fujii, G. C. Frações lábeis e recalcitrantes da matéria orgânica em solos sob integração lavoura-pecuária. Pesquisa Agropecuária Brasileira, v.46, p.1321-1331, 2011. http://dx.doi.org/10.1590/ S0100-204X2011001000028

Silva, I. R.; Mendonça, E. S. Matéria orgânica do solo. In: Novais, R. F.; Venegas, V. H. A.; Barros, N. F. de; Fontes, R. L. F.; Cantarutti, R. B.; Neves, J. C. L. (ed.) Fertilidade do solo. Viçosa: Sociedade Brasileira de Ciência do Solo, 2007. p.275-374.

Strickland, M. S.; Rousk, J. Considering fungal: Bacterial dominance in soils e Methods, controls, and ecosystem implications. Soil Biology \& Biochemistry, v.42, p.1385-1395, 2010. http://dx.doi. org/10.1016/j.soilbio.2010.05.007

Yeomans, J. C.; Bremner, J. M. A. Rapid and precise method for routine determination of organic carbon in soil. Communications in Soil Science Plant Analysis, v.19, p.1467-1476, 1988. http://dx.doi. org/10.1080/00103628809368027 